(2). $\begin{array}{r}2018 \text { Volume 24(2): 383-405 } \\ \text { doi: } 10.3846 / 20294913.2016 .1213192\end{array}$

\title{
BANK PROFITABILITY AND MACROECONOMY: EVIDENCE FROM LITHUANIA
}

\author{
Laurynas NARUŠEVIČIUS \\ Faculty of Mathematics and Informatics, Vilnius University, Naugarduko g. 24, 03225 Vilnius
}

Received 09 September 2014; accepted 22 May 2016

\begin{abstract}
The purpose of this paper is to investigate the relationship between profitability of the Lithuanian banking sector and its internal and external determinants. We use the panel error correction model to assess long-term and short-term determinants of items from bank income statements (net interest income, net fee and commission income and operating expenses). The results of the pooled mean group estimator show that bank size and real GDP are the main determinants in the long-term. Meanwhile, empirical examination suggests various variables as short-term determinants of income statement items. The pooled mean group estimation technique and the analysis of separate income statement items enable us to have a better insight into the Lithuanian banking sector and determinants of its revenue and expenses.
\end{abstract}

Keywords: bank profitability, dynamic panel data, panel error correction model, pooled mean group estimator.

JEL classification: C23, G21, E32.

\section{Introduction}

The banking sector plays an important part in the economy. As one of the main sources for financing of economic activity, banks may influence business cycles. On the other hand, bank revenues show fluctuations in time as they depend on the overall economic activity. Bank profitability is a prime determinant of bank stability and lending capacity. A stable banking sector may stimulate the economy and is able to withstand economic shocks. Therefore, it is important to understand the relationship between bank revenue and macroeconomic variables as it could help assess the stability of a banking sector.

The purpose of this paper is to examine the relationship between the profitability of the Lithuanian banking sector and its determinants. The knowledge of the relationship is useful for banks and their supervisors who are responsible for maintaining a stable finan-

Corresponding author Laurynas Naruševičius

E-mail: laurynas.narusevicius@mif.vu.lt 
cial sector. In this paper we adopt the panel error correction model to assess long-term and short-term internal and external determinants of items from bank income statements (net interest income, net fee and commission income and operating expenses). The pooled mean group (PMG) estimation technique developed by Pesaran et al. (1997, 1999b) allows us to impose homogeneity in the long-term coefficients and enables heterogeneity in the short-term coefficients. Therefore, this study contributes to the sparse literature on the Lithuanian banking sector analysis and introduces an estimation technique which is new in this field of research.

The majority of studies on the relationship between bank profitability and explanatory variables used return on assets or return on equity as the dependent variable. Studies of Goddard et al. (2004) and other analysed cross-country data, meanwhile Athanasoglou et al. (2008), Coffinet and Lin (2010), Dietrich and Wanzenried (2011) analyse data of single separate countries. Studies have found that bank profitability is determined by bank-specific, industry-specific and macroeconomic determinants. Variables used in the studies and effect on profitability differ as data sets vary across studies. Few papers (Andersen et al. 2008; Albertazzi, Gambacorta 2009) have studied determinants of separate items of bank revenue and expenses. However, none of these studies include data on the Lithuanian banking sector in their analysis. Therefore, it is interesting to investigate whether we can find a similar relationship in a transitional economy such as Lithuania.

In this paper we analyse data on the Lithuanian banking sector covering the period from 2004 to 2013. Therefore, this period includes pre-crisis and post-crisis data. The empirical results show that bank size is an important determinant in the long-term of all three items from the income statement. This result reflects the fact that the Lithuanian banking sector is still developing, therefore, bank size allows banks to generate higher revenue, but also causes higher expenses. Furthermore, the overall economic activity also significantly influences the performance of a bank. We determined a statistically significant long-term relationship between real GDP and net interest income as well as operating expenses. Therefore, prior expectations on long-term relationships between dependent variables and explanatory variables are confirmed by empirical results. Empirical estimation suggests various variables as short-term determinants of income statement items. We found that short-term interest rate and credit losses have an influence on net interest income, real export has an impact on net fee and commission income, and compensation per employee has an effect on operating expenses. The pooled mean group estimation technique and analysis of separate income statement items enables us to have a better insight into the Lithuanian banking sector and determinants of its revenue and expenses.

The rest of the paper is structured in the following manner. Section 2 provides review of related empirical literature on bank profitability. Section 3 describes dependent and independent variables used for the analysis. Section 4 presents the estimation method and Section 5 provides the empirical results of this analysis. Finally, Section 6 gives the concluding remarks on our main findings. 


\section{Related literature}

Several studies have attempted to identify internal and external determinants of bank profitability. Bank-specific or internal determinants of profitability come from balance sheets and profit (loss) accounts. Meanwhile, some industry-specific and macroeconomic variables have been proposed for both internal and external determinants, depending on the objective of the study.

A number of studies have analysed profitability of either cross-country or individual countries' banking systems. Cross-country panel data sets have been investigated by Molyneux and Thornton (1992), Demirguc-Kunt and Huizinga (1999), Abreu and Mendes (2002), Goddard et al. (2004), Pasiouras and Kosmidou (2007), Albertazzi and Gambacorta (2009), Goddard et al. (2010), Lee and Hsieh (2013), Shehzad et al. (2013), Gambacorta et al. (2014), Dietrich and Wanzenried (2014). Examples of single countries' analysis are studies of Andersen et al. (2008), Athanasoglou et al. (2008), Apergis (2009), García-Herrero et al. (2009), Coffinet and Lin (2010), Dietrich and Wanzenried (2011), Sufian (2011), Kanas et al. (2012), Rumler and Waschiczek (2012), Trujillo-Ponce (2013), Berlemann et al. (2014), Perman et al. (2015), Chronopoulos et al. (2015). Certainly, the empirical results of the above mentioned studies vary as time periods, data sets, examined environments and countries differ. On the other hand, some internal and external determinants of bank profitability are common across all studies.

The main variables of the profitability measure used in the studies are return on assets (or return on average assets) and return on equity (or return on average equity). Another variable used for the profitability measure is net interest margin, i.e. net interest income divided by total assets.

Most of the studies examined variables such as bank size, capital ratio, operational efficiency and risk measure for bank-specific determinants of profitability. The relationship between size and profitability is found to be negative by Pasiouras and Kosmidou (2007) and Coffinet and Lin (2010). These results support evidence that large banks often face scale inefficiencies and small and medium banks encounter economies of scale and scope. Meanwhile, Goddard et al. (2004) and Athanasoglou et al. (2008) determined a statistically insignificant relationship between size and profitability. An important determinant of bank profitability is the quality of loan portfolio. The effect of credit risk, i.e. loan losses, is clearly significant and negative (Athanasoglou et al. 2008; Coffinet, Lin 2010; Sufian 2011; Kanas et al. 2012). Demirguc-Kunt and Huizinga (1999) and Abreau and Mendes (2002) found that loan to total assets ratio, as a proxy of risk, is positive, meaning that higher risk is rewarded with better profitability. However, this may be true during normal growth periods, but during crises higher risk leads to higher losses and lower profitability.

Results on the relationship between bank capital and profitability are rather interesting. In theory, the expected relationship between the capital adequacy ratio and returns should be negative as a high capital adequacy ratio signalizes that bank is operating overcautiously and ignoring potentially profitable transactions. An empirically negative relationship has been determined by Goddard et al. (2010) and Rumler and Waschiczek (2012). On the contrary, Demirguc-Kunt and Huizinga (1999), Abreu and Mendes (2002), Pasiouras and 
Kosmidou (2007), García-Herrero et al. (2009) took another measure of bank capitalization, i.e. equity over total assets, and determined a strong positive relationship. Authors argue that banks with higher capital ratio indicate higher stability of a bank and its ability to gain profit in the future. This leads to lower costs of funding and, consequently, higher profitability.

Furthermore, several authors found empirical evidence that better operational efficiency has a positive influence on bank profits. Athanasoglou et al. (2008) used overhead costs over total assets, Goddard et al. (2010) and Dietrich and Wanzenried $(2011,2014)$ used the cost-to-income ratio as a measure of operational efficiency. Another internal determinant of profitability is the ownership of a bank. Demirguc-Kunt and Huizinga (1999) argues that foreign ownership has a positive effect on profitability in developing countries and a negative effect in industrial countries. This result supports the fact that foreign banks have technological edge in developing countries and there is no such advantage in industrial countries. Dietrich and Wanzenried (2011) also found that foreign-owned banks are less profitable than Swiss banks.

Many studies also include macroeconomic and other external determinants of bank profitability. Pasiouras and Kosmidou (2007), Albertazzi and Gambacorta (2009), Dietrich and Wanzenried $(2011,2014)$, Rumler and Waschiczek (2012) among others used the annual GDP growth rate to link business cycle and bank earnings. Athanasoglou et al. (2008), Apergis (2009) and Kanas et al. (2012) used output gat as a measure of business cycle. All authors found strong positive correlation between business cycle and bank profitability. Their results support the pro-cyclical feature of bank profits.

Empirical results of Demirguc-Kunt and Huizinga (1999), Abreu and Mendes (2002), Athanasoglou et al. (2008) show a positive impact of inflation on bank profitability. This finding suggests that with inflation bank income increases more than bank costs. Though Dietrich and Wanzenried (2014) argue that inflation has a positive and significant effect in low- and middle-income countries, it does not affect profitability in high income countries. Furthermore, many authors used some measure of interest rates in their researches. Demirguc-Kunt and Huizinga (1999), Abreu and Mendes (2002), García-Herrero et al. (2009) used the short-term interest rate, Albertazzi and Gambacorta (2009) used the longterm interest rate, Coffinet and Lin (2010), Dietrich and Wanzenried (2011) and Rumler and Waschiczek (2012) used the interest rate spread, i.e. the difference between long-term and short-term interest rates. The positive impact of higher interest rates reflects the fact that banks are able to increase lending rates quickly. This result may be due to imperfect market competitive conditions, especially in developing countries.

Market concentration is frequently used as an external determinant of profitability which represents market structure. This variable is related to the structure-conduct-performance (SCP) hypothesis. The SCP (or market-power) hypothesis states that increased market power yields monopoly profits. Research results of Molyneux and Thornton (1992), Demirguc-Kunt and Huizinga (1999) support the SCP hypothesis, i.e. bank concentration is statistically significant, and has a positive influence on profitability. Dietrich and Wanzenried (2011) also found a positive relationship, but the impact was minor. Meanwhile, the empirical results of Claeys and Vennet (2004) have shown that the structure-conduct-performance hypothesis is supported in the market of Western European banks, but is not 
supported in Eastern Europe. Similar results were found by Mirzaei et al. (2013), who state that a greater market share leads to higher profitability in advanced economies, but SCP hypothesis is not supported in emerging economies. However, Athanasoglou et al. (2008) found no evidence to support the SCP hypothesis, the concentration variable was negative and statistically insignificant.

Studies of Albertazzi and Gambacorta (2009) and Andersen et al. (2008) are the most closely related to our research. Albertazzi and Gambacorta (2009) studied not only the relationship between return on equity and other determinants, but also analysed different components of income statements. Authors studied the link between items of income statements (net interest income, non-interest income, operating expenses, provisions and profit before taxes) and internal and external determinants. Albertazzi and Gambacorta (2009) found that GDP has an impact on both net interest income and provisions. Meanwhile, Andersen et al. (2008) analysed aggregated Norwegian banking sector data using the error correction framework. Authors found a long-term co-integrating relationship between net interest income and GDP and the real interest rate and a similar co-integrating relationship between fee income and macroeconomic variables. Andersen et al. (2008) also state that reversion to the long-term relationship is relatively fast in the net income equation and slower in the fee income equation.

Finally, the available literature delivers a comprehensive analysis of internal and external determinants of bank profitability. Nevertheless, the long-term and the short-term relationship between bank income components and bank-specific and macroeconomic variables has not yet been analysed in great detail. Moreover, our study contributes to the relatively sparse amount of literature on the Lithuanian banking sector related to profitability analysis. This new analysis should serve as a relevant addition to the available literature on the determinants of bank profit.

\section{Determinants of bank income and expenses}

In our analysis we extract net interest income, net fee and commission income and operating expenses from bank income statements and analyse them separately. These income statement items are the main components of operating profit of different banks. In this section we describe dependent variables and independent variables (determinants of bank income and expenses) selected for the study.

\subsection{Dependent variables}

Net interest income is the main component of bank revenue. Net interest income is calculated as the difference between interest income and interest expenses. Banks operating in Lithuania are described as traditional banks, i.e. their main business is to provide loans for customers and to collect deposits. Therefore, the main driver of interest income is revenue from loan payments received from customers. Other sources of interest income are less important for banks. Meanwhile, banks finance their activity through deposits and subordinated debts. 
The recent financial crisis had a strong effect on net interest income. The pressure came from both sides, i.e. decreasing interest income and increasing interest expenses. Most of the banks experienced significant decline of net interest income during 2009. From 2010 the trend of net interest income is slightly upward.

Net fee and commission income is the second component of revenue included in our research. Net fee and commission income is calculated as the difference between fee and commission income and fee and commission expenses. Fee on payment transaction and currency exchange transactions are the main elements of net interest income. This income statement item also includes other fee charges from a variety of bank services.

Unlike net interest income, net fee and commission income showed an upward trend throughout the period analysed. The importance of net fee and commission income increased particularly following the crisis as banks tried to compensate for the decline in net interest income by attracting more revenue from fee and commission charges.

Operating expenses include salaries and payments to employees, IT development costs as well as other operating expenses. On average salaries and payments to employees amount to almost 70 percent of total operating expenses. Although there was a decline of operating expenses in 2009 and 2010, expenses began to grow again soon afterwards.

\subsection{Independent variables}

Real gross domestic product $(G D P)$ is used as a measure of overall economic activity in Lithuania. Many studies have determined a positive relationship between GDP and bank profitability (e.g. Demirguc-Kunt, Huizinga 1999; Athanasoglou et al. 2008; Albertazzi, Gambacorta 2009). There are several reasons why bank earnings may be pro-cyclical. First of all, demand for credit usually increases during the upswing of economic cycle as concerns of risks decrease. Secondly, increased demand for loans allows banks to set a wider interest margin. Therefore, the growth of revenue from lending activities could be more rapid than the growth of cost associated with bank financing. An increased demand for bank transactions and other operations also exists during an economic boom. This may lead to higher fee and commission income. The relationship between economic activity and commercial bank revenue may be opposite during economic downswings. Hence we expect to find a relationship between GDP and bank revenue, i.e. net interest income and net fee and commission income.

Many companies that export their products abroad require currency exchange operations and other bank transaction services. Therefore, we include a level of real export as a measure of demand for bank services and expect a positive relationship between real export and net fee and commission income.

Based on the findings of Albertazzi and Gambacorta (2009) and other authors our analysis also includes inflation rate. Albertazzi and Gambacorta (2009) determined a positive and significant relationship between inflation rate and non-interest income as well as operating cost. Commercial banks may react to higher inflation rate by increasing charges on their transactions and operations. On the other hand, a higher inflation rate may put pressure on a bank's operating expenses as prices of different services also increase. Hence, 
we expect that inflation rate has an effect on net fee and commission income and operating expenses.

Three-month VILIBOR is used as a proxy of short-term interest rate. Banks finance long-term loans by taking short-term deposits. Three-month or six-month interest rate is one of the components used to set the price for loans. Therefore, interest rate is an important element for the business of commercial banks as it determines their ability to earn income from their core banking activities. We expect that short-term interest rate will have an influence on net interest income.

Salaries and payments to employees constitute a significant part of operating expenses. Growth of employee wages may raise operating expenses as well. Compensation per employee is used as a proxy for salaries and other payments to employees.

Unemployment rate may also have an impact on operating expenses. Higher unemployment rate allows banks to postpone the rise of salaries or even to cut them. And vice versa, lower unemployment rate enable employees to negotiate better working conditions. Therefore, unemployment rate and its changes may also be important for the ability of banks to control their operating expenses.

In the related literature one of the main questions is whether the size of a bank affects its ability to gain more profit. Larger banks usually have a higher number of products to offer and a bigger customer service network. This allows more cross-selling opportunities as banks have more clients and can offer more services. On the other hand, the effect of size may be negative because of bureaucratic and other reasons. Total assets are used to estimate the relationship between bank size and dependent variables.

Loans provided by banks are the primary source of interest income. Therefore, loan stock (net) is included in the research of determinants for net interest income. Loan stock (net) is used instead of loan stock (gross) to reflect the fact that not all customers are repaying their loans.

Credit losses over loans stock (gross) is used as a measure of credit risk. Banks report their credit losses in their income statements. In theory, higher credit losses show that the quality of loan portfolio is deteriorating. Therefore, the negative effect on net interest income is expected from credit losses over the loans stock (gross) ratio.

The level of loan loss provisions is another measure of a bank's loan portfolio credit risk. Other than credit losses, which is a flow variable, loan loss provisions are a stock variable. A higher level of loan loss provisions indicates that a bigger part of loan portfolio does not generate revenue. Furthermore, banks may improve their credit risk monitoring and evaluation and this will have an effect on future decisions related to portfolio growth and the level of credit risk.

The Herfindahl-Hirschman index $(H H I)$ is used to examine market structure in the Lithuanian banking sector. $H H I$ is calculated as the sum of squares of the market shares of all the banks operating in Lithuania. The SCP hypothesis states that a highly concentrated market may lead to monopoly profits. Banks may pay lower interest rates on deposits and require higher rates on issued loans. On the contrary, a lower HHI in the banking sector might be a result of greater competition. In that case the relationship between market concentration and bank earnings may be negative. Therefore, the relationship between $H H I$ and bank profit is undefined in literature sources and must be analysed empirically. 


\section{Data and methodology}

In this section we describe our data set in more detail and introduce the methodology used to estimate the long-term and the short-term relationship between dependent variables and macroeconomic and bank-specific variables.

\subsection{Data}

In this study we use a data set that contains quarterly data of eight banks operating in Lithuania and covers the period from 2004 to 2013, i.e. $N=8$ and $T=40$. Bank-specific variables (net interest income (NII), net fee and commission income (NCI), operating expenses $(O E)$, total assets $(A)$, loan stock (net) (NLS), credit losses over loans stock (gross) $(C L)$, loan loss provisions $(P R O)$ ) are taken from quarterly income statements and balance sheet reports. All variables are expressed in thousand litas except $C L$ which is calculated as ratio. Macroeconomic variables are taken from the Lithuanian Department of Statistics (Statistics Lithuania). The levels of real GDP (GDP) and real export (REX) are expressed in million litas, compensation per employee $(C P E)$ is expressed in litas, and unemployment rate $(U N R)$ and inflation $(H I C P)$ are expressed in percentages. Three-month VILIBOR $(S T I)$ is taken from the database of the Bank of Lithuania. In order to standardise the level of variables and reduce volatility in further analysis all variables expressed in litas are taken in logs. Descriptive statistics of the data are presented in the Appendix A. Furthermore, pair-wise correlations of dependent and explanatory variables are presented in the Appendix B. Correlation between variables show a potential relationship between them, but the results need to be interpreted with caution as it is estimated between non-stationary variables.

\subsection{Methodology}

Many studies of bank profitability use the dynamic panel approach as profitability or income statement items show persistence in time. In our case we are also using this approach. However, as banks operating in the Lithuanian banking system are obviously heterogeneous, we would like to assess the long-term relationship that is common, but allow for short-term heterogeneous dynamics.

A large number of dynamic panel estimators is provided in the literature on the topic. In this study the pooled mean group (PMG) estimator developed by Pesaran et al. (1997, 1999 b) is chosen as it suits our purpose best. The PMG estimator constrains long-term coefficients across cross-sectional units and at the same time allows intercepts, short-term coefficients and adjustment to the equilibrium relationship do differ. Haque et al. (1999) argue that neglecting cross-sectional heterogeneity in the short-term can lead to misleading inferences about the long-term relationship.

Consider the panel autoregressive distributed lag model ARDL $\left(p, q_{1}, \ldots, q_{n}\right)$ according to which dependent variables are explained by their own lags and by lags of bank-specific and macroeconomic determinants. Given data on cross-sectional units $i=1,2, \ldots, N$ and 
time periods $t=1,2, \ldots, T$, panel ARDL $\left(p, q_{1}, \ldots, q_{n}\right)$ model can be written as follow:

$$
y_{i t}=\mu_{i}+\sum_{j=1}^{p} \lambda_{i j} y_{i, t-j}+\sum_{j=0}^{q_{i}} \delta_{i j}^{\prime} B_{i, t-j}+\sum_{j=0}^{q_{i}} \gamma_{i j}^{\prime} M_{t-j}+\varepsilon_{i t}
$$

where: $y_{i t}$ is the explained variable (net interest margin, net fee and commission income, operating expenses), $B_{i t}$ - bank-specific variables, $M_{t}$ - macroeconomic variables, $\eta_{i}$ - unobserved fixed effects.

Using the first differences of $\operatorname{ARDL}\left(p, q_{1}, \ldots, q_{n}\right)$ specification (Eq. (1)), we can write the following re-parameterization of the model:

$$
\Delta y_{i t}=\phi_{i} y_{i, t-1}+\beta_{i}^{\prime} B_{i t}+\eta_{i}^{\prime} M_{t}+\sum_{j=1}^{p-1} \lambda_{i j}^{*} \Delta y_{i, t-j}+\sum_{j=0}^{q_{i}-1} \delta_{i j}^{* \prime} \Delta B_{i, t-j}+\sum_{j=0}^{q_{i}-1} \gamma_{i j}^{* \prime} \Delta M_{t-j}+\varepsilon_{i t},(2)
$$

where: $\quad \phi_{i}=-\left(1-\sum_{j=1}^{p} \lambda_{i j}\right) ; \quad \beta_{i}=\sum_{j=0}^{q_{i}} \delta_{i j} ; \quad \eta_{i}=\sum_{j=0}^{q_{i}} \gamma_{i j} ; \quad \lambda_{i j}^{*}=-\sum_{m=j+1}^{p} \lambda_{i m}, j=1,2, \ldots, p-1 ;$ $\delta_{i j}^{*}=-\sum_{m=j+1}^{q_{i}} \delta_{i m}, j=1,2, \ldots, q_{i}-1 ; \gamma_{i j}^{*}=-\sum_{m=j+1}^{q_{i}} \gamma_{i m}, j=1,2, \ldots, q_{i}-1$, i.e. coefficients are functions of initial coefficients in the Eq. (1).

Furthermore, the Eq. (2) can be rearranged under the form of a panel error correction equation, i.e. changes in dependent variables are explained by gap from the long-term equilibrium and short-term dynamics of other variables:

$$
\Delta y_{i t}=\phi_{i} y_{i, t-1}+\beta_{i}^{\prime} B_{i t}+\eta_{i}^{\prime} M_{t}+\sum_{j=1}^{p-1} \lambda_{i j}^{*} \Delta y_{i, t-j}+\sum_{j=0}^{q_{i}-1} \delta_{i j}^{* \prime} \Delta B_{i, t-j}+\sum_{j=0}^{q_{i}-1} \gamma_{i j}^{* \prime} \Delta M_{t-j}+\varepsilon_{i t},
$$

where: $\phi_{i}$ - denotes the error correction coefficient or the speed of adjustment to equilibrium values; long-term coefficients: $\alpha_{i}=-\frac{\mu_{i}}{\phi_{i}} ; \beta_{i}^{*}=-\frac{\beta_{i}}{\phi_{i}} ; \eta_{i}^{*}=-\frac{\eta_{i}}{\phi_{i}}$.

Estimation of this model takes the following assumptions:

Assumption 1: the disturbances $\varepsilon_{i t}$ in (1) are independently distributed across $\mathrm{i}$ and $\mathrm{t}$, with means 0 , variances $\sigma_{i}^{2}>0$, and finite fourth-order moments. They are also distributed independently of the regressors.

Assumption 2: ARDL $\left(p, q_{1}, \ldots, q_{n}\right)$ model is stable in that the roots of $\sum_{j=1}^{p} \lambda_{i j} z^{j}=1, i=1,2, \ldots, N$ lie outside the unit circle. This assumption ensures that $\phi_{i}<0$ and hence there exists a long-term relationship. Pesaran et al. (1999a) give the framework for testing assumption 2 .

Assumption 3: (Long-term homogeneity): The long-term coefficients on $B_{i t}$ and $M_{t}$ are the same across the groups, i.e. $\beta_{i}^{*}=\beta^{*}$ and $\eta_{i}^{*}=\eta^{*}, i=1,2, \ldots, N$.

Pesaran and Shin (1999) have shown that ARDL approach yields consistent estimates of the long-term coefficients, irrespective of whether the underlying regressors are $I(1)$ or $I(0)$. We will use panel unit root tests to examine stationarity of the data.

Furthermore, we also use the mean group (MG) estimator developed by Pesaran and Smith (1995) which imposes no restriction on long-term coefficients. The MG estimator 
allows intercepts, short-term coefficients, error correction coefficients and long-term coefficients to differ across cross-sectional units. Pesaran and Smith (1995) have shown that the MG estimator will produce consistent estimates of long-term coefficients. However, the MG estimator will be inefficient in case of long-term homogeneity. Pesaran et al. (1999b) argue that in case of long-term homogeneity the PMG estimator is consistent and efficient. Therefore, the Hausman type test (Hausman 1978) could be applied to the difference between the MG and PMG estimators to test homogeneity of long-term coefficients.

\section{Empirical results}

\subsection{Unit root test}

The first step is to analyse statistical properties of the data set. We used unit root tests to investigate stationarity and order of integration of the data. For dependent variables and bank-specific variables we performed panel unit root tests: Im, Pesaran and Shin developed by Im et al. (2003) and Fisher ADF, Fisher PP proposed by Maddala and Wu (1999) and Choi (2001). For macroeconomic variables we applied the traditional augmented DickeyFuller test (ADF) introduced by Dickey and Fuller (1979).

The null hypothesis for panel unit root tests is that all series contain a unit root. The alternative hypothesis is that the fraction of individual series that follows stationary processes in non-zero. Im et al. (2003) panel unit root estimation is based on averaging individual augmented Dickey-Fuller unit root tests. Meanwhile, Fisher ADF and Fisher PP tests statistic is derived by combining $p$-values from individual unit root tests.

Results of the panel unit root tests of dependent variables are presented in Table 1. All three tests support the hypothesis of a unit root in the data. Furthermore, analysis of first differences shows that dependent variables are integrated of order one. The stationarity of bank-specific explanatory variables was also tested and results are reported in Table 7 (Appendix C). Panel unit root tests show that bank assets, loan stock (net) and provisions are $I(1)$ processes and credit losses are integrated of order $I(0)$.

Table 1. Panel unit root tests (dependent variables)

\begin{tabular}{lcccccc}
\hline \multirow{2}{*}{ Variable } & \multicolumn{2}{c}{ Im, Pesaran and Shin } & \multicolumn{2}{c}{ Fisher ADF } & \multicolumn{2}{c}{ Fisher PP } \\
\cline { 2 - 7 } & Level & $\begin{array}{c}\text { First } \\
\text { differences }\end{array}$ & Level & $\begin{array}{c}\text { First } \\
\text { differences }\end{array}$ & $\begin{array}{c}\text { Level } \\
\text { firferences }\end{array}$ \\
\hline $\begin{array}{l}\text { Net interest } \\
\text { income }\end{array}$ & -0.066 & -8.036 & 18.06 & 90.70 & 21.24 & 479.6 \\
\hline $\begin{array}{l}\text { Net fee and } \\
\begin{array}{l}\text { commision } \\
\text { income }\end{array}\end{array}$ & $-0.474)$ & $(0.000)$ & $(0.321)$ & $(0.000)$ & $(0.170)$ & $(0.000)$ \\
\hline $\begin{array}{l}\text { Operating } \\
\text { expenses }\end{array}$ & -0.073 & -11.92 & 15.22 & 217.3 & 34.98 & 728.7 \\
\hline
\end{tabular}

Notes: p-values are reported in the parenthesis. For Im, Pesaran and Shin, Fisher ADF panel unit root tests number of lags was selected using the AIC criterion. Panel unit root tests include intercept and trend. 
The null hypothesis of the augmented Dickey-Fuller unit root test is that data has unit root, and alternative hypothesis is that data is stationary. The null hypothesis of the ADF test is accepted if test statistics are bigger than MacKinnon (1996) critical value at 5 percent significant level. ADF unit root test results (Table 8, Appendix C) show that all macroeconomic variables, except unemployment rate, are integrated of order one. Unit root test results verify that we can use the pooled mean group estimator. However, unemployment rate may not be a suitable regressor.

\subsection{Co-integration tests}

Panel unit root tests showed that most of the dependent and independent variables are integrated of order one. The second step was to test whether there is a long-term relationship between variables. This relationship was tested using heterogeneous panel co-integration tests proposed by Pedroni $(1999,2004)$. The null hypothesis of no co-integration is tested using residual-based tests. Pedroni $(1999,2004)$ introduced two types of tests: within dimension test and between dimension test. The first type of tests are based on pooling residuals of co-integrating equation along the within dimension. This type includes four statistics: panel $v$, panel $\rho$, panel PP and panel ADF. The second type of tests are based on pooling residuals of co-integrating equation along the between dimension. This type includes three statistics: group $\rho$, group PP and group ADF. Pedroni (1999) stated that all seven appropriately standardized statistics are asymptotically normally distributed.

Panel co-integration tests results presented in Table 9 (Appendix D) show bivariate estimation of co-integration between net interest income and independent variables. The null hypothesis of no co-integration is rejected at the 5 percent significance level. The results show that a strong long-term relationship exists between net interest income and total assets as well as loan stock (net), where null hypothesis of no co-integration was rejected by six out of seven statistics. Results of panel co-integration tests also support the long-term relationship between the dependent variable and macroeconomic variables, i.e. compensation per employee, inflation and short-term interest rate. At the 5 percent significance level three statistics reject the null hypothesis of no co-integration between net interest income and real GDP, but at the 10 percent significance level there are four statistics that reject the null hypothesis.

Table 10 (Appendix D) provides panel co-integration test results of a long-term relationship between net fee and commission income and explanatory variables. The majority of statistic data rejects the null hypothesis of no co-integration between the dependent variable and bank-specific variables (total assets, loan stock (net) and provisions) as well as macroeconomic variables (real GDP, inflation, short-term interest rate compensation per employee, unemployment rate and $H H I$ ). Three out of seven statistics also reject the null hypothesis for real export.

Results of panel co-integration tests between operating expenses and independent variables are presented in Table 11 (Appendix D). Test results show that operating expenses are less dependent on bank-specific and macroeconomic variables than other dependent variables. The null hypothesis is rejected at the 5 percent significance level for total assets, 
loan stock (net) compensation per employee and short-term interest rate. Test results supporting the long-term relationship between operating expenses and short-term interest rate are slightly unexpected. At the 10 percent significance level the null hypothesis is rejected for inflation and real GDP. Panel co-integration test results show that there is no long-term relationship between operating expenses and other explanatory variables.

Panel co-integration tests results confirm that items of income statements (net interest income, net fee and commission income and operating expenses) have a long-term relationship with some explanatory variables. Therefore, it is reasonable to apply the panel error correction model.

\subsection{Net interest income}

After preliminary examination of the data set for stationarity and co-integration we continue our analysis and use the pooled mean group estimation methodology. Therefore, we estimate a separate equation:

$$
\Delta y_{i t}=\phi_{i}\left(y_{i, t-1}-\alpha_{i}-\beta X_{t}\right)-\gamma_{i} \Delta X_{t}+\varepsilon_{i t},
$$

where: $y_{i t}$ - net interest income and $X_{t}$ is bank-specific $\left(B_{i t}\right)$ or macroeconomic variable $\left(M_{t}\right)$. Hence we include one by one determinants of net interest income and estimate Eq. (4) independently of other explanatory variables. Such estimation can give primary information on the importance of variables in the long-term relationship. Of course, their eventual impact may be different as variables also depend on the correlation with other determinants of a dependent variable.

The pooled mean group estimation results ${ }^{1}$ show that bank-specific variables, i.e. total assets and loan stock (net), are statistically significant in the long-term. Furthermore, there are also negative and statistically significant error correction coefficients for those variables. These results indicate that bank size is an important variable determining net interest income. Similarly, PMG estimation results show that there is a statistically significant longterm relationship between net interest income and real GDP as well as compensation per employee. Error correction coefficients were also negative and significantly different from zero. PMG estimation results show that other variables are not statistically significant for net interest income in the long-term.

The final step was estimation of the panel error correction model of net interest income determined by bank-specific and macroeconomic variables. Since we are interested in both long-term and short-term determinants of a dependent variable, we include only two variables in the long-run estimation. Furthermore, we also include two independent variables in the short-term estimation. The variables to be included in the model have been chosen using the following methodology. We begin with the long-term estimation where we choose variables based on results from panel co-integration tests and individual PMG estimation results. Afterwards we include short-term variables selected based on the significance of coefficients and economic meaning of the sign.

\footnotetext{
${ }^{1}$ Pooled mean group estimation results of individual variables are not presented to conserve space, but are available upon request.
} 
Panel co-integration tests and individual PMG estimation show that there is long termrelationship between size (total assets or loan stock (net)) and net interest income. Previous examination of the data set also shows that macroeconomic variables (real GDP and compensation per employee) are an important determinant in the long-term. We estimated an Eq. (3) where one bank-specific and one macroeconomic variable were included in the long-term. Based on the pooled mean group estimation results we include total assets and real GDP in our model as long-term determinants of net interest income. Co-integration of the dependent variable and two independent variables was also tested with panel cointegration tests. Results presented in Table 12 (Appendix E) reject the null hypothesis of no co-integration between these variables.

Short-term determinants of net interest income were selected following examination of contemporaneous and one period lagged variables. Short-term interest rate and one period lagged credit losses were included in the final panel error correction model. The pooled mean group estimation results for the model of net interest income are presented in Table 2.

Table 2. Net interest income estimation results

\begin{tabular}{lcc}
\hline \multirow{2}{*}{ Long term coefficients } & \multicolumn{2}{c}{ Estimation method } \\
\cline { 2 - 3 } & PMG & MG \\
\hline \multirow{2}{*}{$\log (G D P)$} & 1.191 & 1.419 \\
\cline { 2 - 3 } & $(0.005)$ & $(0.027)$ \\
\hline \multirow{2}{*}{$\log (A)$} & 0.556 & 0.443 \\
\hline Short term coefficients & & \\
\hline \multirow{2}{*}{ Error correction } & $-0.000)$ & $(0.007)$ \\
\hline \multirow{2}{*}{$\Delta S T I$} & $(0.000)$ & -0.513 \\
\hline \multirow{2}{*}{$\Delta C L(-1)$} & 0.105 & $0.000)$ \\
\cline { 2 - 3 } & $(0.088)$ & $(0.067)$ \\
\hline \multirow{2}{*}{ Constant } & -0.048 & -0.039 \\
\cline { 2 - 3 } & $(0.040)$ & $(0.059)$ \\
\hline
\end{tabular}

Note: $\mathrm{p}$-values are reported in parenthesis.

The pooled mean group estimation results show that total assets and real GDP have a positive influence on net interest income in the long run. The error correction coefficient is negative and statistically significant at the 5 percent significance level. This result supports the estimated long-term relationship as valid. Albertazzi and Gambacorta (2009) and Andersen et al. (2008) also found similar results for the long-term determinant of net interest income. The Lithuanian banking sector is still developing, therefore, it may gain from economies of scale. Lithuanian banks are too small to face scale inefficiency determined by other authors (Pasiouras, Kosmidou 2007; Coffinet, Lin 2010). Meanwhile, increasing overall economic activity creates bigger demand for loans and banks are able to increase their 
revenue from interest income. A change in three-month VILIBOR has a positive effect on net interest income in the short-term. Similarly to Albertazzi and Gambacorta (2009) and García-Herrero et al. (2009), our finding confirms the fact that banks have marker power and are able to increase lending rates quickly. Estimation results also show that dynamics of loan portfolio quality play an important role in the short-term changes of net interest income. Therefore, signs of the estimated coefficients are in line with our prior expectations.

As a robustness check we performed mean group estimation of the panel error correction model. MG estimator imposes no restriction on long-term coefficients, i.e. it allows heterogeneity in the long-term. The MG estimates of the coefficients are similar to PMG estimates. This is verified by the Hausman test statistic (Hausman 1978) of 0.49, which is $\chi^{2}(2)$ under the null hypothesis of no difference between the PMG and MG estimators. Therefore, we may conclude that the PMG estimator is efficient and preferred over the MG estimator.

\subsection{Net fee and commission income}

The same steps were taken when estimating the long-term and short-term relationship between net fee and commission income and explanatory variables. The pooled mean group estimation results of individual determinant of net fee and commission income show that bank-specific (total assets, loan stock (net)) and macroeconomic variables (real GDP, compensation per employee) are significantly different from zero in the long-term. Furthermore, error correction coefficients were negative and statistically significant at the 5 percent significance level. Although four out of seven panel co-integration test statistics could not reject null hypothesis of no co-integration between net fee and commission income and real export, PMG estimation results suggest otherwise, i.e. the long-term coefficient and the negative error correction coefficient are statistically significant. Therefore, all these variables may be included in the final equation for the net fee and commission income.

The pooled mean group estimation results of net fee and commission income are presented in Table 3. Similarly to the net interest income equation, total assets are also an important determinant of this income statement item in the long-term. Bigger banks are able to offer more products to their customers and, therefore, have more cross-selling opportunities. This result differs from that of Albertazzi and Gambacorta (2009), who found that the size of a bank has a negative impact on net fee and commission income. As for the second explanatory variable, we found that real export influences dynamics of NCI. Higher trade activity requires more currency exchange and other banking operations and, therefore, generates fee and commission income for banks. Error correction coefficient is equal to -0.321 , i.e. less than in NII, but is also significantly negative. Therefore, net interest income is closely related to the size of a bank and economic activity. PMG estimation results were also supported by panel co-integration tests (Table 13, Appendix E) where most of the test statistics reject the null hypothesis.

Short-term dynamics are explained by the lagged value of change in net fee and commission income itself. Moreover, lagged value of change in real export has a positive impact on change in NCI. Other examined variables were not statistically significant in the short-term. 
Table 3. Net fee and commission income estimation results

\begin{tabular}{lcc}
\hline \multirow{2}{*}{ Long term coefficients } & \multicolumn{2}{c}{ Estimation method } \\
\cline { 2 - 3 } & PMG & MG \\
\hline \multirow{2}{*}{$\log ($ REX $)$} & 0.551 & 0.403 \\
\cline { 2 - 3 } & $(0.000)$ & $(0.072)$ \\
\cline { 2 - 3 } $\log (A)$ & 0.321 & 0.444 \\
\hline Short term coefficients & & $(0.000)$ \\
\hline \multirow{2}{*}{ Error correction } & -0.321 & -0.537 \\
\hline \multirow{2}{*}{$\Delta \log (N C I(-1))$} & $(0.000)$ & $(0.000)$ \\
\hline \multirow{2}{*}{$\Delta \log (R E X(-1))$} & -0.191 & -0.094 \\
\hline \multirow{2}{*}{ Constant } & $(0.000)$ & $(0.008)$ \\
\cline { 2 - 3 } & 0.5131 & 0.440 \\
\hline
\end{tabular}

Note: p-values are reported in parenthesis.

The mean group estimation of the error correction model for net fee and commission income gives similar coefficient estimates. However, real export coefficients are less significant than PMG estimates The Hausman test statistic is equal to 0.68 , and, therefore, supports the assumption that homogeneity could be imposed in the long run.

\subsection{Operating expenses}

The last dependent variable for which we estimated long-term and short-term determinants is operating expenses. Similarly to other dependent variables, bank size (total assets or loan stock (net)) is an important determinant for operating expenses. Individual PMG estimation shows that long-term coefficients and negative error correction coefficients are significantly different from zero. Moreover, macroeconomic variables (real GDP and compensation per employee) are also significant determinants for the dependent variable. Contrary to panel co-integration test results, PMG estimation does not support the long-term relationship between operating expenses and short-term interest rate. Other variables were also not significant in the long-term.

Table 4 presents results of the pooled mean group estimation of operating expenses equation. We determined a long-term relationship between $O E$, total assets and the real GDP. The error correction coefficient is the highest among estimated equations and significantly negative. This result suggests that although bank size and overall economic activity is important for the income of banks (NII and NCI), but it increases expenses as well. Bigger banks have more employees and bigger customer service chains. Furthermore, real GDP growth creates initiatives for employees to require salary increase and prices for services supporting banking operations may also rise (panel co-integration tests are given in 
Table 14, Appendix E). These findings are in line with Albertazzi and Gambacorta (2009), who also found a positive impact of total assets and real GDP on operating expenses.

Short-term dynamics of operating expenses are explained by the lagged value of change in operating expenses and by change in compensation per employee. In line with our expectations, $C P E$ is an important determinant of operating expenses and has a positive effect on it because expenses to employees constitute a significant part of operating expenses.

Table 4. Operating income estimation results

\begin{tabular}{|c|c|c|}
\hline \multirow{2}{*}{ Long term coefficients } & \multicolumn{2}{|c|}{ Estimation method } \\
\hline & PMG & MG \\
\hline \multirow{2}{*}{$\log (G D P)$} & 1.035 & 1.240 \\
\hline & $(0.000)$ & $(0.029)$ \\
\hline \multirow{2}{*}{$\log (A)$} & 0.462 & 0.525 \\
\hline & $(0.000)$ & $(0.000)$ \\
\hline \multicolumn{3}{|l|}{ Short term coefficients } \\
\hline \multirow{2}{*}{ Error correction } & -0.535 & -0.674 \\
\hline & $(0.000)$ & $(0.000)$ \\
\hline \multirow{2}{*}{$\Delta \log (O E(-1))$} & -0.203 & -0.173 \\
\hline & $(0.001)$ & $(0.005)$ \\
\hline \multirow{2}{*}{$\Delta \log (C P E)$} & 0.351 & 0.265 \\
\hline & $(0.014)$ & $(0.084)$ \\
\hline \multirow{2}{*}{ Constant } & -4.029 & -5.070 \\
\hline & $(0.000)$ & $(0.005)$ \\
\hline
\end{tabular}

Note: p-values are reported in parenthesis.

Similarly to previous equations, the mean group estimation of error correction model of operating expenses gives close values of coefficients. The estimated Hausman test statistic is equal to 1.83. Therefore, we also conclude that long-term homogeneity could be imposed for operating expenses.

\section{Conclusions}

In this paper we examined the long-term and the short-term relationship between bank profitability and explanatory variables, i.e. we analysed which bank-specific and macroeconomic variables influence income statement items (net interest income, net fee and commission income and operating expenses). We used the data set from the Lithuanian banking sector covering the period from 2004 to 2013, and applied the pool mean group estimator to investigate determinants of bank revenue and expenses.

Empirical results show that the size of a bank expressed as total assets is an important long-term determinant of revenue and expenses. As the Lithuanian banking sector is still developing, banks are not that big that could face scale inefficiencies found in other researches (Pasiouras, Kosmidou 2007; Coffinet, Lin 2010). Lithuanian banks could be at- 
tributed to small and medium size banks and, therefore, they can exploit economies of scale and scope. As expected, economic activity is an important macroeconomic determinant of income statement items. Increasing GDP creates initiatives to borrow and invest more in the economy leading to higher net interest income. On the other hand, increasing economic activity requires banks to meet higher demand for transactions and loan portfolio maintenance, i.e. banks must raise operating expenses. This finding is in line with conclusions of Albertazzi and Gambacorta (2009), Dietrich and Wanzenried (2011) and many others authors who also found a pro-cyclical feature related to bank profits.

Our estimation shows that change in interest rate and change in credit losses has an impact on net interest income in the short-term. A positive influence of the interest rate reflects the fact that banks have the market power to increase lending rate quickly. Similarly to Athanasoglou et al. (2008) and Coffinet and Lin (2010), we found that decreasing quality of loan portfolio lowers the ability of banks to generate revenue, therefore, credit losses have a negative effect on net interest income. Empirical results also show that real export is an important determinant of net fee and commission income in the short-term. Change in demand for currency exchange and other bank operation influences bank revenue from fees and commissions. The short-term relationship between operating expenses and compensation per employee shows that employees' wages constitute a significant part of banks' expenses. All short-term relationships are in line with theoretical expectations.

Other bank-specific and macroeconomic variables were found to be less important or insignificant determinants of bank profitability. SCP hypothesis is not supported as $\mathrm{HHI}$ was found to be an insignificant determinant of all three income statement items and, therefore, not included in the final equations. This result is in line with the findings of Claeys and Vennet (2004) who found no evidence to support the SCP hypothesis in Eastern Europe. However, some of these determinants would be important if we could include them in the models.

The approach used in this study allows us to analyse long-term and short-term determinants of bank revenue and expenses. These results may be used by supervisors of banks as part of the stress testing exercise used to assess stability of the banking sector. However, the pooled mean group estimator requires the data set to be quite large. Therefore, a larger data set on Lithuanian banks would help us to include more determinants in the models and have a better understanding of long-term and short-term relationships. This issue could be addressed in future analyses.

\section{References}

Abreu, M.; Mendes, V. 2002. Commercial bank interest margins and profitability: evidence from E.U. countries. Working Paper Series, Porto.

Albertazzi, U.; Gambacorta, L. 2009. Bank profitability and the business cycle, Journal of Financial Stability 5(4): 393-409. https://doi.org/10.1016/j.jfs.2008.10.002

Andersen, H.; Berg, S. A.; Jansen E. S. 2008. The dynamics of operating income in the Norwegian banking sector. Norges Bank Working Paper 13.

Apergis, N. 2009. Bank profitability over different business cycles regimes: evidence from panel threshold models, Banks and Bank Systems 4(3): 59-70. 
Athanasoglou, P. P.; Brissimis, S. N.; Delis, M. D. 2008. Bank-specific, industry-specific and macroeconomic determinants of bank profitability, Journal of International Financial Markets, Institutions and Money 18(2): 121-136. https://doi.org/10.1016/j.intfin.2006.07.001

Berlemann, M.; Oestmann, M.; Thum, M. 2014. Demographic change and bank profitability: empirical evidence from German savings banks, Applied Economics 46(1): 79-94. https://doi.org/10.1080/00036846.2013.829262

Choi, I. 2001. Unit root tests for panel data, Journal of International Money and Finance 20(2): 249-272. https://doi.org/10.1016/S0261-5606(00)00048-6

Chronopoulos, D. K.; Liu, H.; McMillan, F. J.; Wilson, J. 2015. The dynamics of US bank profitability, The European Journal of Finance 21(5): 426-443. https://doi.org/10.1080/1351847X.2013.838184

Claeys, S.; van der Vennet, R. 2004. Determinants of bank interest margins in Central and Eastern Europe: a comparison with the West, Economic Systems 32(2): 197-216. https://doi.org/10.1016/j.ecosys.2007.04.001

Coffinet, J.; Lin, S. 2010. Stress testing banks' profitability: the case of French banks. Banque de France. Working paper No. 306.

Demirguc-Kunt, A.; Huizinga, H. 1999. Determinants of commercial bank Interest margins and profitability: some international evidence, World Bank Economic Review 13(2): 379-408. https://doi.org/10.1093/wber/13.2.379

Dickey, D. A.; Fuller, W. A. 1979. Distribution of the estimators for autoregressive time series with a unit root, Journal of the American Statistical Association 74: 417-431. https://doi.org/10.1080/01621459.1979.10482531

Dietrich, A.; Wanzenried, G. 2011. Determinants of bank profitability before and during the crisis: evidence from Switzerland, Journal of International Financial Markets, Institutions and Money, 21(3): 307-327. https://doi.org/10.1016/j.intfin.2010.11.002

Dietrich, A.; Wanzenried, G. 2014. The determinants of commercial banking profitability in low-, middle-, and high-income countries, The Quarterly Review of Economics and Finance 54(3): 337-354. https://doi.org/10.1016/j.qref.2014.03.001

Gambacorta, L.; Scatigna, M.; Yang. J. 2014. Diversification and bank profitability: a nonlinear approach, Applied Economics Letters 21(6): 438-441. https://doi.org/10.1080/13504851.2013.866196

García-Herrero, A.; Gavilá, S.; Santabárbara, D. 2009. What explains the low profitability of Chinese banks?, Journal of Banking and Finance 33(11): 2080-2092.

https://doi.org/10.1016/j.jbankfin.2009.05.005

Goddard, J.; Liu, H.; Molyneux, P.; Wilson, J. 2010. Do bank profits converge? European Financial Management 19(2): 346-365. https://doi.org/10.1111/j.1468-036X.2010.00578.x

Goddard, J.; Molyneux, P.; Wilson, J. 2004. The profitability of European Banks: a cross-sectional and dynamic panel analysis, Manchester School 72(3): 363-381. https://doi.org/10.1111/j.1467-9957.2004.00397.x

Haque, N. U.; Pesaran, M. H.; Sharma, S. 1999. Neglected heterogeneity and dynamics in cross-country savings regressions. International Monetary Fund Working paper No. 99/128.

Hausman, J. A. 1978. Specification tests in econometrics, Econometrica 46(6): 1251-1271. https://doi.org/10.2307/1913827

Im, K. S.; Pesaran, M. H.; Shin, Y. 2003. Testing for unit roots in heterogeneous panels, Journal of Econometrics 115(1): 53-74. https://doi.org/10.1016/S0304-4076(03)00092-7

Kanas, A.; Vasiliou, D.; Eriotis, N. 2012. Revisiting bank profitability: a semi-parametric approach, Journal of International Financial Markets, Institutions and Money 22(4): 990-1005.

https://doi.org/10.1016/j.intfin.2011.10.003 
Lee, C.; Hsieh, M. 2013. The impact of bank capital on profitability and risk in Asian banking, Journal of International Money and Finance 32: 251-281. https://doi.org/10.1016/j.jimonfin.2012.04.013

MacKinnon, J. G. 1996 Numerical distribution functions for unit root and cointegration tests, Journal of Applied Econometrics 11: 601-618. https://doi.org/10.1002/(SICI)1099-1255(199611)11:6<601::AID-JAE417>3.0.CO;2-T

Maddala, G. S.; Wu, S. 1999. A comparative study unit root tests with panel data and a new simple test, Oxford Bulletin of Economics and Statistics 61(S1): 631-652. https://doi.org/10.1111/1468-0084.61.s1.13

Mirzaei, A.; Moore, T.; Liu, G. 2013. Does market structure matter on banks' profitability and stability? Emerging vs. advanced economies, Journal of Banking and Finance 37(8): 2920-2937. https://doi.org/10.1016/j.jbankfin.2013.04.031

Molyneux, P.; Thornton, J. 1992. Determinants of European Bank Profitability: a note, Journal of Banking and Finance 16(6): 1173-1178. https://doi.org/10.1016/0378-4266(92)90065-8

Pasiouras, F.; Kosmidou, K. 2007. Factors influencing the profitability of domestic and foreign commercial banks in the European Union, Research in International Business and Finance 21(2): 222-237. https://doi.org/10.1016/j.ribaf.2006.03.007

Pedroni, P. 1999. Critical values for cointegration tests in heterogeneous panels with multiple regressors, Oxford Bulletin of Economics and Statistics 61(S1): 653-70. https://doi.org/10.1111/1468-0084.61.s1.14

Pedroni, P. 2004. Panel cointegration: asymptotic and finite sample properties of pooled time series tests with an application to the PPP hypothesis, Econometric Theory 20(3): 597-625. https://doi.org/10.1017/S0266466604203073

Perman, M.; Pelivan, I.; Arnerić, J. 2015. Profit persistence and determinants of bank profitability in Croatia, Economic Research 28(1): 284-298.

Pesaran, H.; Shin, Y.; Smith, R. J. 1999a. Bounds testing approaches to the analysis of long run relationships. Cambridge working papers in Economics, No. 9907.

Pesaran, H.; Shin, Y.; Smith, R. P. 1997. Pooled estimation of long-run relationships in dynamic heterogeneous panels. Cambridge working papers in Economics, No. 9721.

Pesaran, H.; Shin, Y.; Smith, R. P. 1999b. Pooled mean group estimation of dynamic heterogeneous panels, Journal of the American Statistical Association 94(446): 621-634. https://doi.org/10.1080/01621459.1999.10474156

Pesaran, H.; Smith, R. P. 1995. Estimating long-run relationships from dynamic heterogeneous panels, Journal of Econometrics 68(1): 79-113. https://doi.org/10.1016/0304-4076(94)01644-F

Pesaran, M. H.; Shin, Y. 1999. An autoregressive distributed lag modelling approach to cointegration analysis, Chapter $11 \mathrm{in} \mathrm{S.} \mathrm{Strom} \mathrm{(Ed.).} \mathrm{Econometrics} \mathrm{and} \mathrm{Economic} \mathrm{Theory} \mathrm{in} \mathrm{the} \mathrm{20}{ }^{\text {th }}$ Century: The Ragnar Frisch Centennial Symposium. Cambridge University Press.

Rumler, F.; Waschiczek, W. 2012. Have changes in the financial structure affected bank profitability? Evidence for Austria. Oesterreichische Nationalbank. Workink paper series, No. 180.

Shehzad, C. T.; De Haan, J.; Scholtens, B. 2013. The relationship between size, growth and profitability of commercial banks, Applied Economics 45(13): 1751-1765. https://doi.org/10.1080/00036846.2011.637896

Sufian, F. 2011. Profitability of the Korean banking sector: panel evidence on bank-specific and macroeconomic determinants, Journal of Economics and Management 7(1): 43-72.

Trujillo-Ponce, A. 2013. What determines the profitability of banks? Evidence from Spain, Accounting and Finance 53(2): 561-586. https://doi.org/10.1111/j.1467-629X.2011.00466.x 


\section{Appendix A: Descriptive statistics}

Table 5. Descriptive statistics

\begin{tabular}{lcccc}
\hline \multicolumn{1}{c}{ Dependent variables } & Mean & Std. dev. & Min & Max \\
\hline $\log (N I I)$ & 9.79 & 1.23 & 6.97 & 12.03 \\
\hline $\log (N C I)$ & 8.79 & 1.30 & 6.41 & 11.04 \\
\hline $\log (O E)$ & 9.62 & 1.04 & 7.53 & 11.37 \\
\hline \multicolumn{1}{c}{ Independent variables } & & & & \\
\hline $\log (G D P)$ & 9.89 & 0.09 & 9.71 & 10.02 \\
\hline $\log ($ REX $)$ & 9.48 & 0.23 & 9.04 & 9.88 \\
\hline$H I C P$ & 3.84 & 3.14 & -1.10 & 12.26 \\
\hline$S T I$ & 3.15 & 2.20 & 0.40 & 8.02 \\
\hline $\log (C P E)$ & 8.90 & 0.21 & 8.42 & 9.14 \\
\hline$U N R$ & 10.75 & 4.47 & 4.17 & 18.15 \\
\hline $\log (A)$ & 15.15 & 1.31 & 11.98 & 17.07 \\
\hline $\log (N L S)$ & 14.83 & 1.37 & 11.51 & 16.87 \\
\hline$C L$ & 0.27 & 0.65 & -1.45 & 4.72 \\
\hline $\log (P R O)$ & 10.79 & 2.28 & 1.39 & 14.43 \\
\hline$H H I$ & 0.19 & 0.01 & 0.16 & 0.21 \\
\hline
\end{tabular}

\section{Appendix B: Pair wise correlations}

Table 6. Pair wise correlations

\begin{tabular}{lccc}
\hline & $\log ($ NII $)$ & $\log (N C I)$ & $\log (O E)$ \\
\hline $\log ($ GDP $)$ & 0.311 & 0.224 & 0.268 \\
\hline $\log ($ REX $)$ & 0.265 & 0.230 & 0.257 \\
\hline$H I C P$ & 0.182 & 0.070 & 0.112 \\
\hline$S T I$ & 0.061 & 0.002 & 0.023 \\
\hline $\log (C P E)$ & 0.335 & 0.260 & 0.307 \\
\hline$U N R$ & 0.026 & 0.055 & 0.058 \\
\hline $\log (A)$ & 0.955 & 0.880 & 0.934 \\
\hline $\log (N L S)$ & 0.946 & 0.853 & 0.918 \\
\hline$C L$ & -0.094 & -0.045 & -0.072 \\
\hline $\log (P R O)$ & 0.694 & 0.702 & 0.720 \\
\hline$H H I$ & -0.143 & -0.078 & -0.108 \\
\hline
\end{tabular}




\section{Appendix C: Unit root tests}

Table 7. Panel unit root tests (bank-specific variables)

\begin{tabular}{lcccccc}
\hline \multirow{2}{*}{ Variable } & \multicolumn{2}{c}{ Im, Pesaran and Shin } & \multicolumn{2}{c}{ Fisher ADF } & \multicolumn{2}{c}{ Fisher PP } \\
\cline { 2 - 7 } & Level & $\begin{array}{c}\text { First } \\
\text { differences }\end{array}$ & Level & $\begin{array}{c}\text { First } \\
\text { differences }\end{array}$ & Level & $\begin{array}{c}\text { First } \\
\text { differences }\end{array}$ \\
\hline \multirow{2}{*}{ Loan stock (net) } & 2.644 & -5.548 & 3.837 & 68.41 & 8.522 & 79.43 \\
\cline { 2 - 7 } & $(0.996)$ & $(0.000)$ & $(0.999)$ & $(0.000)$ & $(0.932)$ & $(0.000)$ \\
\hline \multirow{2}{*}{ Total assets } & 0.261 & -6.849 & 12.98 & 84.58 & 8.344 & 131.5 \\
\cline { 2 - 7 } & $(0.603)$ & $(0.000)$ & $(0.674)$ & $(0.000)$ & $(0.938)$ & $(0.000)$ \\
\hline \multirow{2}{*}{ Provisions } & 1.210 & -5.727 & 12.05 & 68.77 & 3.025 & 106.6 \\
\hline \multirow{2}{*}{ Credit loss } & $(0.887)$ & $(0.000)$ & $(0.741)$ & $(0.000)$ & $(0.999)$ & $(0.000)$ \\
\hline & -2.536 & -20.976 & 31.79 & 440.5 & 58.19 & 955.8 \\
\hline
\end{tabular}

Notes: p-values are reported in the parenthesis. For Im, Pesaran and Shin, Fisher ADF panel unit root tests number of lags was selected using the AIC criterion. Panel unit root tests include intercept and trend.

Table 8. Unit root test (macroeconomic variables)

\begin{tabular}{lcc}
\hline \multirow{2}{*}{ Variable } & \multicolumn{2}{c}{ ADF } \\
\cline { 2 - 3 } $\log (G D P)$ & Level & First differences \\
\hline \multirow{2}{*}{$\log ($ REX $)$} & -2.520 & -4.463 \\
\cline { 2 - 3 } & $(0.317)$ & $(0.005)$ \\
\hline \multirow{2}{*}{$H I C P$} & -2.515 & -5.233 \\
\cline { 2 - 3 } & $(0.320)$ & $(0.001)$ \\
\hline \multirow{2}{*}{$S T I$} & -3.098 & -3.924 \\
\hline \multirow{2}{*}{$\log (C P E)$} & $(0.121)$ & $(0.020)$ \\
\hline \multirow{2}{*}{ UNR } & -1.799 & -4.426 \\
\cline { 2 - 3 } & $(0.687)$ & $(0.006)$ \\
\hline \multirow{2}{*}{$H H I$} & -1.666 & -5.257 \\
\cline { 2 - 3 } & $(0.748)$ & $(0.001)$ \\
\hline
\end{tabular}

Notes: p-values are reported in the parenthesis.

Number of lags was selected using the AIC criterion. Unit root test includes intercept and trend. 


\section{Appendix D: Co-integration with individual variables}

Table 9. Panel co-integration tests (net interest income)

\begin{tabular}{lccccccc}
\hline & $\begin{array}{c}\text { Panel } \\
\text { v-Statistic }\end{array}$ & $\begin{array}{c}\text { Panel } \\
\text { rho-Statistic }\end{array}$ & $\begin{array}{c}\text { Panel } \\
\text { PP-Statistic }\end{array}$ & $\begin{array}{c}\text { Panel } \\
\text { ADF-Statistic }\end{array}$ & $\begin{array}{c}\text { Group } \\
\text { rho-Statistic }\end{array}$ & $\begin{array}{c}\text { Group } \\
\text { PP-Statistic }\end{array}$ & $\begin{array}{c}\text { Group } \\
\text { ADF-Statistic }\end{array}$ \\
\hline $\log (G D P)$ & 0.731 & 0.013 & 0.000 & 0.000 & 0.702 & 0.054 & 0.691 \\
\hline $\log (R E X)$ & 0.774 & 0.005 & 0.000 & 0.000 & 0.845 & 0.523 & 0.511 \\
\hline$H I C P$ & 0.526 & 0.000 & 0.000 & 0.000 & 0.179 & 0.020 & 0.016 \\
\hline$S T I$ & 0.335 & 0.000 & 0.000 & 0.000 & 0.463 & 0.147 & 0.019 \\
\hline $\log (C P E)$ & 0.002 & 0.000 & 0.000 & 0.000 & 0.020 & 0.001 & 0.000 \\
\hline$U N R$ & 0.903 & 0.001 & 0.000 & 0.000 & 0.773 & 0.670 & 0.318 \\
\hline $\log (A)$ & 0.560 & 0.000 & 0.000 & 0.000 & 0.005 & 0.000 & 0.000 \\
\hline $\log (N L S)$ & 0.716 & 0.000 & 0.000 & 0.000 & 0.032 & 0.002 & 0.000 \\
\hline$C L$ & 0.000 & 0.312 & 0.898 & 0.831 & 0.941 & 0.992 & 0.336 \\
\hline $\log (P R O)$ & 0.599 & 0.000 & 0.000 & 0.000 & 0.504 & 0.141 & 0.019 \\
\hline$H H I$ & 0.718 & 0.001 & 0.000 & 0.000 & 0.704 & 0.313 & 0.301 \\
\hline
\end{tabular}

Notes: p-values are reported. Number of lags was selected using the AIC criterion. Co-integration tests include intercept and trend.

Table 10. Panel co-integration tests (net fee and commission income)

\begin{tabular}{lccccccc}
\hline & $\begin{array}{c}\text { Panel } \\
\text { v-Statistic }\end{array}$ & $\begin{array}{c}\text { Panel } \\
\text { rho-Statistic }\end{array}$ & $\begin{array}{c}\text { Panel } \\
\text { PP-Statistic }\end{array}$ & $\begin{array}{c}\text { Panel } \\
\text { ADF-Statistic }\end{array}$ & $\begin{array}{c}\text { Group } \\
\text { rho-Statistic }\end{array}$ & $\begin{array}{c}\text { Group } \\
\text { PP-Statistic }\end{array}$ & $\begin{array}{c}\text { Group } \\
\text { ADF-Statistic }\end{array}$ \\
\hline $\log (G D P)$ & 0.217 & 0.000 & 0.000 & 0.780 & 0.000 & 0.000 & 0.000 \\
\hline $\log (R E X)$ & 0.577 & 0.000 & 0.000 & 0.760 & 0.260 & 0.009 & 0.439 \\
\hline$H I C P$ & 0.000 & 0.000 & 0.000 & 0.544 & 0.005 & 0.000 & 0.030 \\
\hline$S T I$ & 0.090 & 0.000 & 0.000 & 0.000 & 0.014 & 0.000 & 0.000 \\
\hline $\log (C P E)$ & 0.056 & 0.000 & 0.000 & 0.000 & 0.000 & 0.000 & 0.000 \\
\hline$U N R$ & 0.024 & 0.000 & 0.000 & 0.954 & 0.001 & 0.000 & 0.160 \\
\hline $\log (A)$ & 0.054 & 0.000 & 0.000 & 0.000 & 0.000 & 0.000 & 0.000 \\
\hline $\log (N L S)$ & 0.067 & 0.000 & 0.000 & 0.000 & 0.000 & 0.000 & 0.000 \\
\hline$C L$ & 0.333 & 0.000 & 0.000 & 0.000 & 0.453 & 0.477 & 0.373 \\
\hline $\log (P R O)$ & 0.002 & 0.000 & 0.000 & 0.000 & 0.016 & 0.000 & 0.002 \\
\hline$H H I$ & 0.068 & 0.000 & 0.000 & 0.000 & 0.245 & 0.008 & 0.007 \\
\hline
\end{tabular}

Notes: p-values are reported. Number of lags was selected using the AIC criterion. Co-integration tests include intercept and trend. 
Table 11. Panel co-integration tests (operating expenses)

\begin{tabular}{lccccccc}
\hline & $\begin{array}{c}\text { Panel } \\
\text { v-Statistic }\end{array}$ & $\begin{array}{c}\text { Panel } \\
\text { rho-Statistic }\end{array}$ & $\begin{array}{c}\text { Panel } \\
\text { PP-Statistic }\end{array}$ & $\begin{array}{c}\text { Panel } \\
\text { ADF-Statistic }\end{array}$ & $\begin{array}{c}\text { Group } \\
\text { rho-Statistic }\end{array}$ & $\begin{array}{c}\text { Group } \\
\text { PP-Statistic }\end{array}$ & $\begin{array}{c}\text { Group } \\
\text { ADF-Statistic }\end{array}$ \\
\hline $\log (G D P)$ & 0.733 & 0.080 & 0.020 & 0.557 & 0.058 & 0.008 & 0.540 \\
\hline $\log (R E X)$ & 0.958 & 0.882 & 0.520 & 0.336 & 0.944 & 0.665 & 0.144 \\
\hline$H I C P$ & 0.079 & 0.053 & 0.014 & 0.015 & 0.155 & 0.024 & 0.081 \\
\hline$S T I$ & 0.030 & 0.009 & 0.001 & 0.002 & 0.095 & 0.003 & 0.010 \\
\hline $\log (C P E)$ & 0.065 & 0.000 & 0.000 & 0.073 & 0.000 & 0.000 & 0.006 \\
\hline$U N R$ & 0.553 & 0.514 & 0.227 & 0.602 & 0.428 & 0.132 & 0.483 \\
\hline $\log (A)$ & 0.159 & 0.000 & 0.000 & 0.000 & 0.000 & 0.000 & 0.000 \\
\hline $\log (N L S)$ & 0.212 & 0.000 & 0.000 & 0.000 & 0.000 & 0.000 & 0.000 \\
\hline$C L$ & 0.903 & 0.943 & 0.929 & 0.980 & 0.986 & 0.981 & 0.983 \\
\hline $\log (P R O)$ & 0.379 & 0.321 & 0.049 & 0.290 & 0.591 & 0.121 & 0.531 \\
\hline$H H I$ & 0.680 & 0.568 & 0.213 & 0.226 & 0.696 & 0.240 & 0.263 \\
\hline
\end{tabular}

Notes: p-values are reported. Number of lags was selected using the AIC criterion. Co-integration tests include intercept and trend.

\section{Appendix E: Co-integration (long term variables)}

Table 12. Panel co-integration tests (long term variables of NII equation)

\begin{tabular}{ccccccc}
\hline $\begin{array}{c}\text { Panel } \\
\text {-Statistic }\end{array}$ & $\begin{array}{c}\text { Panel } \\
\text { rho-Statistic }\end{array}$ & $\begin{array}{c}\text { Panel } \\
\text { PP-Statistic }\end{array}$ & $\begin{array}{c}\text { Panel } \\
\text { ADF-Statistic }\end{array}$ & $\begin{array}{c}\text { Group } \\
\text { rho-Statistic }\end{array}$ & $\begin{array}{c}\text { Group } \\
\text { PP-Statistic }\end{array}$ & $\begin{array}{c}\text { Group } \\
\text { ADF-Statistic }\end{array}$ \\
\hline-0.967 & -3.457 & -10.667 & -10.155 & -1.306 & -5.212 & -5.043 \\
\hline$(0.833)$ & $(0.000)$ & $(0.000)$ & $(0.000)$ & $(0.096)$ & $(0.000)$ & $(0.000)$ \\
\hline
\end{tabular}

Notes: p-values are reported in parenthesis. Number of lags was selected using the AIC criterion. Co-integration tests include intercept and trend.

Table 13. Panel co-integration tests (long term variables of NCI equation)

\begin{tabular}{ccccccc}
\hline $\begin{array}{c}\text { Panel } \\
\text { v-Statistic }\end{array}$ & $\begin{array}{c}\text { Panel } \\
\text { rho-Statistic }\end{array}$ & $\begin{array}{c}\text { Panel } \\
\text { PP-Statistic }\end{array}$ & $\begin{array}{c}\text { Panel } \\
\text { ADF-Statistic }\end{array}$ & $\begin{array}{c}\text { Group } \\
\text { rho-Statistic }\end{array}$ & $\begin{array}{c}\text { Group } \\
\text { PP-Statistic }\end{array}$ & $\begin{array}{c}\text { Group } \\
\text { ADF-Statistic }\end{array}$ \\
\hline 1.039 & -10.083 & -16.715 & -17.527 & -3.527 & -7.694 & -6.630 \\
\hline$(0.149)$ & $(0.000)$ & $(0.000)$ & $(0.000)$ & $(0.000)$ & $(0.000)$ & $(0.000)$ \\
\hline
\end{tabular}

Notes: p-values are reported in parenthesis. Number of lags was selected using the AIC criterion. Co-integration tests include intercept and trend.

Table 14. Panel co-integration tests (long term variables of OE equation)

\begin{tabular}{ccccccc}
\hline $\begin{array}{c}\text { Panel } \\
\text {-Statistic }\end{array}$ & $\begin{array}{c}\text { Panel } \\
\text { rho-Statistic }\end{array}$ & $\begin{array}{c}\text { Panel } \\
\text { PP-Statistic }\end{array}$ & $\begin{array}{c}\text { Panel } \\
\text { ADF-Statistic }\end{array}$ & $\begin{array}{c}\text { Group } \\
\text { rho-Statistic }\end{array}$ & $\begin{array}{c}\text { Group } \\
\text { PP-Statistic }\end{array}$ & $\begin{array}{c}\text { Group } \\
\text { ADF-Statistic }\end{array}$ \\
\hline 0.976 & -5.862 & -9.143 & -8.637 & -5.446 & -13.468 & -8.216 \\
\hline$(0.165)$ & $(0.000)$ & $(0.000)$ & $(0.000)$ & $(0.000)$ & $(0.000)$ & $(0.000)$ \\
\hline
\end{tabular}

Notes: p-values are reported in parenthesis. Number of lags was selected using the AIC criterion. Co-integration tests include intercept and trend.

Laurynas NARUŠEVIČIUS. 2012-present Vilnius University, Faculty of Mathematics and Informatics, Doctoral (PhD) studies in econometrics. 2008-2010 Vilnius University, Faculty of Mathematics and Informatics, Master degree in econometrics. 2004-2008 Vilnius University, Faculty of Mathematics and Informatics, bachelor degree in econometrics. 2007 autumn Athens University of Economics and Business, ERASMUS programme. 